\title{
МЕТОДОЛОГІЧНІ ОСНОВИ ПІДГОТОВКИ НОРМАТИВІВ ПЛАТИ ЗА СПЕЦІАЛЬНЕ ВИКОРИСТАННЯ РЕСУРСІВ МИСЛИВСЬКИХ УГІДЬ ДЕРЖАВНИХ ПІДПРИЄМСТВ ЛІСОВОГО ГОСПОДАРСТВА
}

Ведення мисливського господарства є невід'ємною складовою частиною суспільного використання природних ресурсів. Це особлива галузь, що розвивалася одночасно із розвитком людини. Ї̈ї вклад у сучасний стан людства важко переоцінити. Хоча самі тлумачення понять "мисливства", "полювання", "добування" давно змінили свою первозданну сутність та значення й у розвиненій цивілізованій системі еколого-економічних відносин переросли у поняття "ведення мисливського господарства". Це комплексний, складний, науковий підхід до охорони, відтворення та невиснажливого, раціонального користування ресурсами мисливських угідь і тварин. Ведення мисливського господарства мають провадити люди, що дійсно люблять природу і є спеціалістами своєї справи. При цьому особливу роль відводять державному регулюванню через відповідні важелі стимулювання раціонального ведення мисливського господарства. Одним з таких важелів має стати дієвий механізм справляння плати за спеціальне використання ресурсів мисливських угідь. У роботі досліджено підходи до визначення плати за спеціальне використання мисливських угідь та самого механізму справляння плати. Відзначено основні умови дієвості запропонованої методики та ії недоліки. Запропоновано більш універсальну методику, яка є простішою для розрахунків та менш часозатратною.

Ключові слова: нормативи плати; мисливські угіддя; платне користування; економічна складова; екологічна складова.

Вступ. Мисливське господарство України є складовою частиною процесу природокористування. Має свої особливості розвитку, що формувалися від давніх часів, під впливом державотворення, деструктивних політичних процесів та еколого-економічних відносин. 3 огляду на це сучасне мисливське господарювання бажало бути би кращим. Значного негативного впливу завдає браконьєрство, корупція, недостатнє, а часто і зовсім відсутне, державне фінансування, невиконання плану біотехнічних робіт, недостатній об'єктивний контроль 3 боку громадськості, застарілі стереотипи сприйняття полювання як розваги для високопосадовців тощо. Окрім цього, мисливські угіддя України істотно розпорошені між різними користувачами, що часто не приділяють їм належної уваги через певні об'єктивні та суб'єктивні чинники. Окрім цього, чинні закони, нормативні акти та положення, що стосуються використання ресурсів мисливських угідь, є непослідовними, недосконалими і мало дієвими.

Вважаємо, що саме запровадження нормативів плати за спеціальне використання ресурсів мисливських угідь шляхом використання єдиної методології їх розрахунку стане одним 3 перших стимулюючих чинників покращення їх якісного стану.

Проблеми щодо визначення нормативів плат за спе- ціальне використання мисливських ресурсів, їх еколого-економічної оцінки та стимулювання дотримання засад сталого розвитку в контексті мисливського господарства досліджено у працях Ю. Ю. Туниці, П. К. Диньки, І. М. Синякевича, Ю. В. Муравйова, О. Р. Проціва, I. Є. Сенька, В. С. Лебедєва та ін. (Tunytcia, Gunianskii \& Veres, 1987; Syniakevych \& Dudiuk, 2005; Muraviov, 2001; Myronenko et al., 2015; Protsiv, 2015).

Туниця Ю. Ю. пропонує застосовувати інтегральну еколого-економічну оцінку мисливських ресурсів, які $\epsilon$ компонентом лісу, тобто відкритої динамічної системи (DMFR) (Tunytcia, Gunianskii \& Veres, 1987). I. М. Синякевич мисливські ресурси відносить до складових, що формують національну цінову політику у лісовому господарстві, та поділяє продукцію мисливського господарства у цьому контексті на мисливські угіддя (ринок продукції лісовирощування), на послуги, що сприяють розвитку мисливського господарства (ринок продукції лісогосподарського виробництва) та на продукцію полювання (ринок продукції лісозаготівель) (Syniakevych \& Dudiuk, 2005).

Принцип комплексності присутній також у методиці розрахунку плати за використання мисливських угідь та фауни Ю. В. Муравйова. Для вартісної оцінки мисливських ресурсів Ю. В. Муравйов запропонував розра-

\section{Інформація про авторів:}

Муравйов Юрій Володимирович, канд. екон. наук, доцент, кафедра менеджменту організацій і адміністрування.

Email: muravjov@i.ua

Гринь Христина Юріївна, аспірантка, кафедра ландшафтної архітектури. Email: krystinka@i.ua

Цитування за ДСтУ: Муравйов Ю. В., Гринь Х. Ю. Методологічні основи підготовки нормативів плати за спеціальне використання ресурсів мисливських угідь державних підприємств лісового господарства. Науковий вісник НлтУ України. 2019, т. 29, № 8. C. 84-87.

Citation APA: Muraviov, Yu. V., \& Hryn, Kh. Yu. (2019). Methodological basis of payment regulations for the special use of the resources of government forestry enterprises. Scientific Bulletin of UNFU, 29(8), 84-87. https://doi.org/10.36930/40290814 
ховувати оптимальне значення ціни ліцензії на полювання, яке базується на мінімальному (на основі собівартості охорони, утримання та відтворення тваринних ресурсів) та максимальному (на основі економічного ефекту для суспільства) рівнях платежів (Muraviov, 2001).

Об'єкт дослідження - сучасна законодавчо-нормативна база України та наукові дослідження стосовно необхідності та методології платежів за спеціальне використання мисливських угідь. Мета дослідженняудосконалення методологічних підходів стосовно розрахунку нормативів плати за спеціальне використання мисливських угідь. Методи дослідження - емпіричні методи наукового дослідження.

Результати дослідження та їх обговорення. Мисливські угіддя та ресурси фауни є складовою частиною природних ресурсів, зокрема - лісових. Закони, нормативні акти та положення, які прийняті стосовно використання природних ресурсів, через свою недосконалість $\epsilon$ недостатньо дієвими. В повній мірі це стосується і мисливського господарства. Поганий стан нормативноправового забезпечення мисливського господарства України призвів до того, що плата за спеціальне використання мисливських угідь і ресурсів мисливської фауни, які є невід'ємними компонентами лісових ресурсів, до цього часу не справляється. Результатом відсутності таких платежів $є$ те, що користувачі не мають стимулу до раціонального використання мисливських угідь і ресурсів мисливської фауни, а державний та місцеві бюджети - недоодержують кошти від мисливсько-господарської діяльності; мисливські угіддя використовуються неефективно, особливо угіддя з бідними кормовими та захисними властивостями, а ресурси мисливських тварин не завжди характеризуються високими кількісними та якісними показниками. Причиною такого стану є недосконалий економічний механізм, який до цього часу функціонує в мисливському господарстві України. Відсутня досконала методика та нормативи плати за спеціальне використання лісових мисливських угідь та фауни як інструмента реалізації екологічної політики. Вирішення цієї проблеми є актуальним для підвищення ефективності ведення мисливського господарства в Україні, оскільки це перший крок у напрямі його реформування на засадах нової екологічної політики.

Наведемо деякі витримки із Закону України "Про мисливське господарство та полювання" та "Про внесення змін до деяких законодавчих актів України з питань мисливського господарства, полювання та рибальства, охорони, використання і відтворення тваринного світу (Zakon Ukrainy, 2000, 2010):

1) "Ведення мисливського господарства здійснюється користувачем мисливських угідь відповідно до погоджених територіальним органом центрального органу виконавчої влади, що реалізує державну політику у сфері лісового та мисливського господарства, проектів організації і розвитку мисливського господарства та укладених 3 ними договорів про умови ведення мисливського господарства".

2) "Вимоги до складання проектів організації і розвитку мисливського господарства, а також форма договору про умови ведення мисливського господарства встановлюється центральним органом виконавчої влади, що формує політику у сфері лісового та мисливського господарства за погодженням центрального органу ви- конавчої влади, що забезпечує формування і реалізацію державної політики у сфері охорони навколишнього природного середовища".

3) "Мисливські угіддя надаються у користування на строк не менше ніж 15 років. Площа мисливських угідь, що надаються користувачеві, повинна становити не менше 3 тис. га, але не більше ніж 35 \% від загальної площі мисливських угідь".

4) "Особа, зацікавлена в отриманні у користування мисливських угідь, звертається до територіального органу центрального органу виконавчої влади, що реалізує державну політику у сфері лісового та мисливського господарства 3 клопотанням про надання у користування мисливських угідь, у якому зазначається найменування та юридична адреса заявника, територія, місце розташування мисливських угідь, а також строк, на який особа зацікавлена отримати їх у користування".

5) "Для потреб мисливського господарства користувачі мисливських угідь мають право у встановленому порядку, за згодою власників або користувачів земельних ділянок, будувати на мисливських угіддях необхідні будівлі та біотехнічні споруди, вирощувати кормові культури, створювати захисні насадження, проводити штучне обводнення, здійснювати інші заходи, пов'язані 3 веденням мисливського господарства, які не суперечать законодавству та інтересам власників або користувачів земельних ділянок".

6) "Користування мисливськими угіддями є платним. Розмір та порядок внесення плати за користування мисливськими угіддями визначаються у договорі між користувачем мисливських угідь та власником або постійним користувачем земельних ділянок, на яких знаходяться ці угіддя. Розмір плати за користування мисливськими угіддями встановлюється залежно від їх місцезнаходження, природної якості та інших чинників".

7) "Переважне право на користування мисливськими угіддями мають:

- власники та постійні користувачі земельних ділянок;

- користувачі мисливських угідь, які продовжують строк користування цими угіддями".

Це є логічним, оскільки за користування не своїм майном потрібно платити. В Україні з багатьох причин не існує єдиного підходу до визначення нормативів плати за спеціальне використання мисливських угідь, що знаходяться на території державних підприємств лісового господарства. Хоча в історичному аспекті такі платежі існували і виконували свої функції.

Так, у "Польщі Станиславівський воєвода видав розпорядження від 16 травня 1923 р., в якому зобов'язав старостів через високу інфляцію прив'язати вартість оренди права полювання до вартості зайця, а саме: вартість оренди 40 га мисливських угідь повинна була становити не менше, ніж вартість однієї голови зайця" (Protsiv, 2015).

Цікавим видається досвід Швейцарії, де існує три системи дозволів на полювання, і кожен регіон обирає свою. Перша - державна, "де полювати можуть лише державні єгері". Друга - "орендна, коли місцева організація мисливців орендує угіддя і має не лише право полювати на цій території, а й здійснювати "менеджмент" популяції - проводити обліки, визначати план добування і т.ін., тобто діє своєрідна саморегуляція". Третя система - "ліцензійна, затверджені державою квоти на полювання розподіляються між мисливцями і дають їм право полювати на території всього штату". Для отримання права полювати сплачують або за ліцензії на до- 
бування, або за оренду угідь. Аналогічна система діє і в Кореї: "ліцензійна система передбачає державну власність на об'єкти дикої природи, тому уряд займається тваринами; система "за дільницями" - право на диких тварин і право полювати на них належить землевласнику, але він зобов'язаний контролювати їх чисельність i стан середовищ їх перебування" (Zakon Ukrainy, 2019).

У Чехії держава зовсім по-іншому ставиться до мисливської галузі - надає дотації на її потреби. Мисливці ж мають "право безкоштовно полювати в рамках наданої квоти, за умови членства у мисливському товаристві". "Таким способом у країні встановлено взаємовигідні відносини між державою, мисливськими господарствами та мисливцями, які в кінцевому підсумку працюють на благо навколишнього середовища". Так само право безкоштовно полювати членам мисливських колективів надається мисливцям Угорщини. В обох країнах обов'язковою умовою є лише платність користування мисливськими угіддями (Zakon Ukrainy, 2019).

Комуністична влада на західних землях України відмінила рішення попередньої влади Австрії та Польщі щодо плати за користування мисливськими угіддями та здійснила націоналізацію всієї землі. Норму про оплату за користування мисливськими угіддями було скасовано (Protsiv, 2015). Незважаючи на чинні закони, положення, інструкції, методики, в Україні сьогодні немає єдиної думки щодо підходів визначення плати за спеціальне використання мисливських угідь та самого механізму справляння плати. Ми також досліджували це питання і запропонували методику розрахунку (Muraviov, 2001) нормативів плати за спеціальне використання ресурсів лісових мисливських угідь, що пройшла апробацію і могла стати основою для розрахунку таких платежів не лише в лісових угіддях, але й інших.

Методику для визначення нормативів плати за спеціальне використання мисливських угідь пропонували у такому вигляді (Muraviov, 2001):

$$
P=\frac{1}{1000} \sum_{i=1}^{n}\left(Z_{i}^{\max } \cdot N_{i}+Z_{i}^{\min } \cdot N_{i} \cdot \frac{q_{i}}{100} \cdot K_{i} \cdot \frac{100-b_{i}}{100} \cdot S_{i} \cdot V_{i}\right),
$$

де: $P$ - норматив плати за спеціальне використання мисливських угідь, грн/га; $Z_{i}^{\max }-$ максимальна ціна відстрільної картки (ліцензії) $i$-го виду мисливської фауни, грн/тварину; $N_{i}$ - оптимальна чисельність мисливських тварин $i$-го виду на 1000 га мисливських угідь, тварин; $Z_{i}^{\min }$ - мінімальна ціна відстрільної картки (ліцензії) $i$-го виду фауни, грн/тварину; $q_{i}$ - частка статевозрілих самок $i$-го виду в числі мисливських тварин, \%; $K_{i}-$ можливий приріст мисливської фауни від однієї самки $i$-го виду, тварин; $b_{i}-$ природний відпад приросту мисливської фауни $i$-го виду, \%; $S_{i}$ - площа $i$ го мисливського угіддя, га; $V_{i}-$ норма відстрілу мисливських тварин певного виду, \%; $n$ - кількість видів мисливської фауни.

Головна суть запропонованої методики в тому, щоб розрахувати економічну оцінку 1 га лісових мисливських угідь через встановлення мінімального та максимального рівнів плати за спеціальне використання ресурсів мисливських тварин. Економічна складова цієї методики полягає в економічному стимулюванні раціонального використання ресурсів мисливських угідь через покращення їх якості, а отже - і збільшення економічної оцінки. Екологічна частина зазначає, що ресурси мисливських тварин є частиною живої природи, для якої властивими є розмноження та природний відпад. Враховуючи еколого-економічні складові, норматив плати за спеціальне використання ресурсів лісових мисливських угідь - це результат множення еколого-економічної оцінки на встановлену норму добування мисливських тварин відповідного виду.

Було зазначено, що умовами дієвості запропонованої методики є:

- обов'язковість планування і калькулювання собівартості вирощування окремих видів мисливських тварин суб'єктами, що займаються веденням мисливського господарства;

- нормативи плати за спеціальне використання ресурсів мисливських угідь встановлюються з урахуванням їх бонітету, екологічної та економічної доступності для добування ресурсів мисливських тварин.

Як уже зазначено вище, цю методику було апробовано, зокрема у Волинському та Львівському обласних управліннях лісового та мисливського господарства, але подальшого впровадження, розвитку та використання вона не знайшла з певних причин, через які в нас не працює ціла низка постанов, указів, законів тощо.

Водночас, як на нашу думку, однією 3 таких об'єктивних причин може бути певна складність та тривалість розрахунку за запропонованою методикою. Тому пропонуємо іншу, також власну методику, яка, можливо, $є$ простіша для розрахунків, потребує зовсім небагато затрат часу і $є$ універсальною для різних типів мисливських угідь:

$$
P=\sum_{i=1}^{n} L_{i} \cdot V_{i} / \sum_{i=1}^{n} O_{i} \cdot V_{i}
$$

де: $P$ - норматив плати за спеціальне використання мисливських угідь, грн/га; $L_{i}-$ ліміт добування $i$-го виду ресурсів мисливських тварин на площі угідь, що надана у користування, особин; $V_{i}-$ вартість ліцензії (відстрільної карточки) на право на полювання $i$-го виду ресурсів мисливських тварин на площі угідь, що надана у користування, особин; $O_{i}$ - отримано ліцензій на добування $i$-го виду ресурсів мисливських тварин на площі угідь, що надана у користування, шт.

Економічна суть іï полягає у максимізації економічного ефекту за використання ресурсів мисливських угідь через доведення чисельності мисливських тварин до оптимального, покращення їх якісного складу та трофейних характеристик, добре організованого процесу полювання, навчання та етичної поведінки мисливців. Отже, такий підхід стимулюватиме власників, користувачів мисливських угідь до покращення їх стану, а каталізатором такого користування мають стати багаті на дичину мисливські угіддя, задоволені інтереси мисливців, висока прибутковість мисливських господарств.

Висновки. За результатами проведеного дослідження встановлено:

- система управління мисливським господарством України потребує змін;

- зміни повинні бути позитивними у напрямку гнучкої системи державного фінансування мисливської галузі, організації проведення необхідних біотехнічних заходів, створення сучасних умов функціювання лісової охорони та єгерської служби, доведення ресурсів мисливських тварин до оптимальної чисельності, залучення громадськості до контрольних та моніторингових дій у процесі ведення мисливського господарства тощо;

- окрім державної підтримки, надавати можливість мисливським господарствам самостійно розпоряджатися кош- 
тами, отриманими від реалізації ліцензій (відстрільних карточок), плати за користування мисливськими угіддями. 3 отриманих коштів сплачувати податки до місцевих бюджетів. Наприклад, від реалізації ліцензій (відстрільних карточок) сплачувати податок як із прибутку, а з отриманої плати за користування мисливських угідь іншими суб'єктами - як податок з доданої вартості;

- введення плати за користування мисливськими угіддями $\epsilon$ давно на часі та логічно обгрунтована в багатьох наукових дослідженнях і знайшла свою підтримку в опитуванні керівників мисливських господарств;

- запропонована нами удосконалена методика визначення плати за спеціальне використання ресурсів мисливських угідь $€$ простіша від раніше розробленої та потребує небагато затрат часу для розрахунків;

- еколого-економічна суть нормативів плати за спеціальне використання ресурсів мисливських угідь $\epsilon$ стимулююча до раціонального їх використання та фінансова до отримання відповідних коштів. Власник угідь отримує кошти, а користувач оберігає та ефективно використовує їх з максимально еколого-економічною вигодою;

- при наданні у користування мисливських угідь більш прискіпливо аналізувати майбутніх користувачів на предмет їх місії господарювання, досвіду, стажу, інноваційних рішень, господарської та фінансової бази тощо;

- систематично здійснювати виховну та просвітницьку роботу серед населення, особливо з молоддю (перегляд фільмів, лекції, екскурсії, конкурси, зустрічі з екологами тощо) щодо усвідомлення того, що природа, яка нас оточує, $є$ нашим джерелом життя, за яким потрібно доглядати, свідомо використовувати та примножувати для багатьох прийдешніх поколінь.

\section{Перелік використаних джерел}

Muraviov, Yu. V. (2001). Normatyvy platy za spetsialne vykorystannia lisovykh myslyvskykh yhid ta fauny yak istrument realizatsii ekolohichnoi polityky. Candidate dissertation for economic sciences (08.08.01 - Economics of Nature Management and Environmental Protection). Lviv, 200 p. [In Ukrainian].

Myronenko, M. O., Sheremet, I. M., Protsiv, O. R., et al. (2015). Proekt modeli reformuvannia i rozvytku myslyvskoho hospodarstva Ukrainy. Retrieved from: http://www.fleg.org.ua/docs/1274. [In Ukrainian].

Protsiv, O. R. (2015). Plata za korystuvannia myslyvskymy uhiddiamy chy koruptsiinyi podatok? Poliuvannia ta rybolovlia, 10. Retrieved from: http://www.fleg.org.ua/konkurs-2016/1290. [In Ukrainian].

Syniakevych, I. M., \& Dudiuk, V. S. (2005). Kontseptsiia natsionalnoi tsinovoi polityky v lisovomu hospodarstvi Ukrainy. Scientific Bulletin of UNFU, 15(7), 145-151. [In Ukrainian].

Tunytcia, Iu. Iu., Gunianskii, I. I., \& Veres, V. F. (1987). Kompleksnoe lesnoe khoziaistvo. Moscow: Agropromizdat, 215 p. [In Russian].

Zakon Ukrainy. (2019). Analiz rehuliatornoho vplyvu do proektu Zakonu Ukrainy "Pro vnesennia zmin do Zakonu Ukrainy "Pro myslyvske hospodarstvo ta poliuvannia" (shchodo platy za korystuvannia myslyvskymy uhiddiamy). Retrieved from: http://dklg.kmu.gov.ua/forest/control/uk/publish/article?art id=155 382\&cat_id=104547 [In Ukrainian].

Zakon Ukrainy. (2000). Pro myslyvske hospodarstvo ta poliuvannia. Vidomosti Verkhovnoi Rady Ukrainy, 18, 132. [In Ukrainian].

Zakon Ukrainy. (2010). Pro vnesennia zmin do deiakykh zakonodavchykh aktiv Ukrainy z pytan myslyvskoho hospodarstva, poliuvannia ta rybalstva, okhorony, vykorystannia i vidtvorennia tvarynnoho svitu. Vidomosti Verkhovnoi Rady Ukrainy, 10, 108. [In Ukrainian].

Yu. V. Muraviov, Kh. Yu. Hryn

Ukrainian National Forestry University, Lviv, Ukraine

\section{METHODOLOGICAL BASIS OF PAYMENT REGULATIONS FOR THE SPECIAL USE OF THE RESOURCES OF GOVERNMENT FORESTRY ENTERPRISES}

Due to the lack of clarity in the hunting legislation regarding the provision of hunting grounds for use and payment for them, the prosecution for poaching, the procedure for issuing shooting cards, the state price policy in the sphere of use, reproduction and protection of hunting resources is ineffective and hinders Ukraine's transition to market-based European relations. This situation leads to a loss-making sector (payback in Ukraine does not exceed $50 \%$ ) and a decrease in the reproduction rate of most livestock species in comparison with European countries. Hunting is an integral part of the public use of natural resources. For the most part, it is a painstaking, high-cost process for the proper quality of habitats, breeding, and other resources of game animals, in other words, creating an appropriate (where required) quality level of their range. In addition, it monitors the resources of game animals, namely their quantitative and qualitative composition, assistance in the fight against diseases, severe climatic seasonal events, etc. The article explores approaches to determining the fee for special use of hunting grounds and the mechanism of payment. The authors have noted basic conditions of effectiveness of the proposed method. Hunting resources include animal resources, products of their livelihoods (within hunting grounds) and hunting products. They are the main object and, at the same time, the resource of the hunting economy, however, the high level of poaching, the corruption of the hunting industry, the imperfection of the regulatory framework, insignificant protection measures and the lack of an elementary culture of hunting have a negative impact on hunting resources. The improvement of the negative situation will help facilitate the normative base of the hunting economy, which would become an instrument of Ukraine's transition to sustainable development of this sphere of management. As a result of the conducted research we found that it is worth analyzing more carefully the future users of hunting grounds for their mission of management, experience, and innovative solutions.

Keywords: payment standards; hunting grounds; paid use; economic component; environmental component. 